\title{
Article \\ Combined Effects of Optimized Heat Treatment and Nickel Coating for the Improvement of Interfacial Bonding in Aluminum-Iron Alloys Hybrid Structures
}

\author{
Gihoon Moon (D) and Eunkyung Lee*
}

Interdisciplinary Major of Maritime AI convergence, Department of Ocean Advanced Materials Convergence Engineering, Korea Maritime and Ocean University, Busan 49112, Korea; mgh1252@naver.com

* Correspondence: elee@kmou.ac.kr; Tel.: +82-51-410-4353

Citation: Moon, G.; Lee, E.

Combined Effects of Optimized Heat Treatment and Nickel Coating for the Improvement of Interfacial Bonding in Aluminum-Iron Alloys Hybrid

Structures. Appl. Sci. 2021, 11, 1501. https://doi.org/10.3390/app11041501

Academic Editor: Theodore Matikas

Received: 7 January 2021

Accepted: 3 February 2021

Published: 7 February 2021

Publisher's Note: MDPI stays neutral with regard to jurisdictional claims in published maps and institutional affiliations.

Copyright: (c) 2021 by the authors. Licensee MDPI, Basel, Switzerland. This article is an open access article distributed under the terms and conditions of the Creative Commons Attribution (CC BY) license (https:/ / creativecommons.org/licenses/by/ $4.0 /)$.
Abstract: The effects of nickel coating and heat treatment on the interfacial bonds of aluminum-iron $(\mathrm{Al} / \mathrm{Fe})$ alloys hybrid structures were investigated using microstructural analysis. The application of a nickel coating successfully suppressed the formation of defects such as gaps and oxide scale, improving the physical bonding of the interface. Optimizing the heat treatment conditions generated superior chemical bonding at the interface and facilitated the formation of a nickel-bearing phase in the $\mathrm{Al}$ matrix. Also, the types of nickel-bearing phase were influenced by solution treatment and proximity to the interface. By analyzing the isopleth phase diagram of the aluminum system for the ranges of nickel present in the $\mathrm{Al}$, it was confirmed that the $\mathrm{Ni}: \mathrm{Cu}$ ratio affected the precipitation characteristics of the system. However, when heated under conditions that were optimized for chemical bonding, the $\mathrm{Al}$ matrix decreased by approximately $40 \%$ (from $100 \mathrm{HV}$ to $60 \mathrm{HV}$ ), due to grain growth. The effect of artificial aging increased the hardness of the Al matrix away from the interface by $35 \%$ (from $63 \mathrm{HV}$ to $90 \mathrm{HV}$ ). On the other hand, this did not occur in the $\mathrm{Al}$ matrix near the interface. These results indicate that the nickel that diffused into the $\mathrm{Al}$ matrix interfered with the precipitation hardening effect.

Keywords: nickel coating; nickel-bearing intermetallic phases; heat treatment; diffusion-bonding; interfaces; microstructure

\section{Introduction}

The demand for high-performance aluminum alloys has increased in the automotive industry in recent years due to their numerous advantages, including high strength-toweight ratios (for reducing vehicle weight, which also improves fuel efficiency), excellent anti-corrosion characteristics, and superior thermal conductivities [1-4]. However, aluminum alloys are not suitable for certain automotive parts that require excellent mechanical properties and wear resistance, such as brake disks, engine blocks, and cylinder heads. This is because of their low Young's modulus and vulnerability to high temperature [5]. To reduce the weight of specific parts and improve their heat dissipation characteristics, several studies have shifted their focus on aluminum-iron $(\mathrm{Al} / \mathrm{Fe})$ alloys hybrid structures combining aluminum and ferrous alloys [5-7]. These structures are being fabricated with the liquid-solid casting process based on the method of pouring liquid alloy onto a monoclinic insert of a steel plate as in many previous studies [8-10]. The fabricated structures in this method can combine the advantages of each metal $[6,7]$.

A prerequisite for efficient hybrid structures is an excellent bond between the two metals. This is essential for achieving good mechanical properties and thermal conduction [11]. Two major complications, however, render the bonding of aluminum and ferrous alloys a quite challenging task. First, these alloys are susceptible to oxidation, leading to oxides that interfere with interfacial bonding. Second, the different physical/thermal properties 
of the two metals, such as the melting points and thermal expansion coefficients, induce poor wettability $[5-7,11,12]$. Therefore, a new process that overcomes these issues must be developed to achieve successful bonding.

The intermediate layer between ferrous and aluminum alloys has played a role in mitigating oxidation and improving joint performance, according to much previous research. The formation of the intermediate layer which contributes to obtaining an excellent bonding has been carried out by the hot dipping method. Coating materials have been selected from zinc, aluminum, and copper $[2,5,7,11,13-15]$. These coatings can effectively prevent direct interaction between steel and aluminum alloys and avert the oxidation of steel during the preheating stage, thus improving bonding $[5-7,13,14]$. There are few studies, however, on the effects of nickel coatings. Nickel coatings can enhance the corrosion resistance of metal objects $[16,17]$, and nickel atoms can also augment the mechanical properties of aluminum alloys at elevated temperatures [18-20] due to their "impurity atom" behavior. Our research aimed to utilize the unique characteristics of nickel, with the aim of improving the interfacial bonding and mechanical properties of $\mathrm{Al} / \mathrm{Fe}$ alloys hybrid structures.

In this work, we applied a nickel coating on an $\mathrm{Al} / \mathrm{Fe}$ alloys hybrid structure, which was fabricated using a dissimilar casting technique. Then, various heat treatment conditions were implemented to evaluate the effects of nickel diffusion on the interfacial bonding and the microstructure of the Al matrix. We aimed to determine the optimized conditions to achieve superior chemical bonding. The chemical bonding mechanism under optimized heat treatment conditions was investigated and compared with thermodynamic calculations for an aluminum alloy system with a 1-10\% nickel concentration range. Finally, hardness tests were performed to assess the combined effects of optimized heat treatment and nickel diffusion on the mechanical properties of the $\mathrm{Al} / \mathrm{Fe}$ alloys hybrid structure.

\section{Materials and Methods}

A total of 316 stainless steel and A319 alloys were used to fabricate the $\mathrm{Al} / \mathrm{Fe}$ alloys hybrid structures. The chemical composition of each alloy is shown in Table 1. Prior to the dissimilar casting process, the 316 stainless steel was coated with nickel by arc wire spraying (the detailed processing parameters are listed in Tables 1 and 2). The aluminum alloy ingots were melted in an electric crucible at $750{ }^{\circ} \mathrm{C}$ and then degassed with argon gas for $10 \mathrm{~min}$. Subsequently, nickel-coated steel plates preheated at $300^{\circ} \mathrm{C}$ were placed on the metal mold. The molten aluminum was then poured into the metal mold, thereby fabricating the $\mathrm{Al} / \mathrm{Fe}$ alloys hybrid structure after solidification.

Table 1. Chemical composition of the A319, SS316, and Ni-5wt.\% Al alloys (wt.\%).

\begin{tabular}{|c|c|c|c|c|c|c|c|}
\hline A319 & Si & $\mathrm{Cu}$ & Mg & $\mathrm{Fe}$ & Al & & \\
\hline Content & 7.98 & 2.8 & 0.64 & 0.74 & Bal. & & \\
\hline SS316 & $\mathrm{Cr}$ & $\mathrm{Ni}$ & Mo & Mn & $\mathrm{C}$ & Si & $\mathrm{Fe}$ \\
\hline Content & 19.11 & 11.23 & 1.98 & 1.64 & 0.219 & 0.181 & Bal. \\
\hline $\mathrm{Ni}-5 w \mathrm{w} \% \mathrm{Al}$ & Al & Mn & $\mathrm{Ti}$ & Si & $\mathrm{Fe}$ & $\mathrm{Cu}$ & $\mathrm{Ni}$ \\
\hline Content & $4.5 \sim 5.5$ & $<0.3$ & $<0.4$ & $<0.5$ & $<0.3$ & $<0.08$ & Bal. \\
\hline
\end{tabular}

Table 2. Processing parameters of arc wire spraying.

\begin{tabular}{cccccccc}
\hline $\begin{array}{c}\text { Coating } \\
\text { Material }\end{array}$ & Voltage (V) & Current (A) & $\begin{array}{c}\text { Wire Diameter } \\
(\mathbf{m m})\end{array}$ & $\begin{array}{c}\text { Air Pressure } \\
(\mathbf{p s i})\end{array}$ & $\begin{array}{c}\text { Spray } \\
\text { Distance }(\mathbf{m m})\end{array}$ & $\begin{array}{c}\text { Spray Gum Moving } \\
\text { Speed }\left(\mathbf{m m} \cdot \mathbf{s}^{-\mathbf{1}}\right)\end{array}$ & $\begin{array}{c}\text { Thickness } \\
(\boldsymbol{\mu m})\end{array}$ \\
\hline $\mathrm{Ni}-5 \mathrm{wt} \% \mathrm{Al}$ & $28 \sim 32$ & $200 \sim 220$ & $\varphi 1.6$ & 100 & 150 & 300 & 200 \\
\hline
\end{tabular}

Heat treatment processes, involving solution treatment and artificial aging, were applied to the fabricated $\mathrm{Al} / \mathrm{Fe}$ alloys hybrid structures. To determine the optimal heat treat- 
ment conditions for chemical bonding, different solution treatment temperatures/times and cooling rates were conducted in this work. As-cast samples were heat-treated at $500^{\circ} \mathrm{C}$, $530^{\circ} \mathrm{C}$, and $550^{\circ} \mathrm{C}$ in an electric furnace. The solution treatment times varied from $1 \mathrm{~h}$, to $3 \mathrm{~h}$, to $8 \mathrm{~h}$ at each temperature, followed by either air- or furnace-cooling. Artificial aging was performed at $170{ }^{\circ} \mathrm{C}$ for $8 \mathrm{~h}$, followed by air-cooling.

The Al/Fe alloys hybrid structures were cut into samples using an electrical discharge machine. The samples were then polished with silicon carbide $(\mathrm{SiC})$ polishing papers (up to grit \#2400). The polishing process was then repeated using $0.25 \mu \mathrm{m}$ diamond and $0.04 \mu \mathrm{m}$ colloidal suspensions. The microstructure of the $\mathrm{Al} / \mathrm{Fe}$ alloys hybrid structure was analyzed using field emission scanning electron microscopy (FE-SEM, MIRA3, Tescan), with an attached an energy-dispersive X-ray spectroscopy (EDS, EDAX) module. To study the effects of the nickel coating, the surface of the nickel-coated steel samples before and after the preheating process was analyzed with X-ray diffraction (XRD, D/MAX $2500 \mathrm{~V} \mathrm{~L} / \mathrm{PC}$, Rigaku) using Cu K $\alpha$ radiation $(\lambda=1.54 \AA$ ) generated at $40 \mathrm{kV}$ and $30 \mathrm{~mA}$. The chemical compositions of the intermetallic phases generated at the interface and in the $\mathrm{Al}$ matrix were studied by EDS. The element diffusions and chemical bonding in the $\mathrm{Al} / \mathrm{Fe}$ alloys hybrid structure, under as-cast and optimized heat treatment conditions, were analyzed using an electron probe X-ray microanalyzer (EPMA, JXA-8230, JEOL).

To analyze the influence of nickel diffusion on the $\mathrm{Al}$ matrix during the heat treatment process, JmatPro®software was used, which calculates equilibrium phases as a function of temperature and input composition. Using this program, we investigated the formation of the nickel-bearing phase in relation to nickel addition in the A319 (Al-Si-Cu-Mg-Fe) alloy system. The equilibrium conditions of the various nickel-bearing phases in this alloy system were investigated at the $0-10 \%$ nickel range and are presented in corresponding isopleth phase diagrams.

The microhardness distribution of the $\mathrm{Al} / \mathrm{Fe}$ alloys hybrid structure was measured using a Vickers hardness testing machine (HM-122, Akashi), with the preset parameters of load stress $=0.1 \mathrm{kgf}$ and time duration $=15 \mathrm{~s}$. By measuring the microhardness across the interface of the $\mathrm{Al} / \mathrm{Fe}$ alloys hybrid structure, the change in hardness of each matrix in relation to heat treatment could be analyzed.

\section{Results and Discussion}

\subsection{Effects of the Nickel Coating on the Interfacial Microstructures}

Figure 1 shows the results of various analyses performed to investigate the effects of the nickel coating on the Al/Fe alloys hybrid structure. Figure 1a shows SEM micrographs of the $\mathrm{Al} / \mathrm{Fe}$ alloys hybrid structure's interface with nickel coating. The interfacial bonding exhibited superior physical bonding performance and was free from defects such as gaps and oxides. In conventional dissimilar casting processes used to fabricate $\mathrm{Al} / \mathrm{Fe}$ alloys hybrid structures (such as diffusion bonding), solid-state steel is combined with a liquid-state aluminum alloy [21]. Considering the substantially different physicochemical properties of $\mathrm{Fe}$ and $\mathrm{Al}$, however, severe oxidation occurs on the surface of steel during the pre-heating stage, thus hindering the bonding of solid-state steel and liquid-state aluminum alloy $[5-7,12]$. The oxide film prevents direct contact during the casting process, reducing the wettability between the metals, and thus results in poor bonding [6]. The nickel-coated steel in this study, however, enabled improved interfacial bonding by preventing oxide formation.

To examine the effects of the nickel coating in more detail, XRD patterns were obtained from the nickel-coated steel before and after the pre-heating step at $300{ }^{\circ} \mathrm{C}$ (Figure $1 \mathrm{~b}$ ). The XRD pattern from the surface of the nickel-coated steel did not change even after preheating at $300{ }^{\circ} \mathrm{C}$, and no nickel oxide peak was detected. This shows that the nickel coating successfully suppressed the formation of an oxide film on the steel surface during preheating, and improved wettability between the aluminum melt and steel, leading to excellent physical bonding of the $\mathrm{Al} / \mathrm{Fe}$ alloys hybrid structure [22]. It was therefore confirmed that preventing oxidation on the steel surface using a nickel coating is an 
effective way to improve the interfacial bonding of the $\mathrm{Al} / \mathrm{Fe}$ alloys hybrid structure fabricated by dissimilar casting.
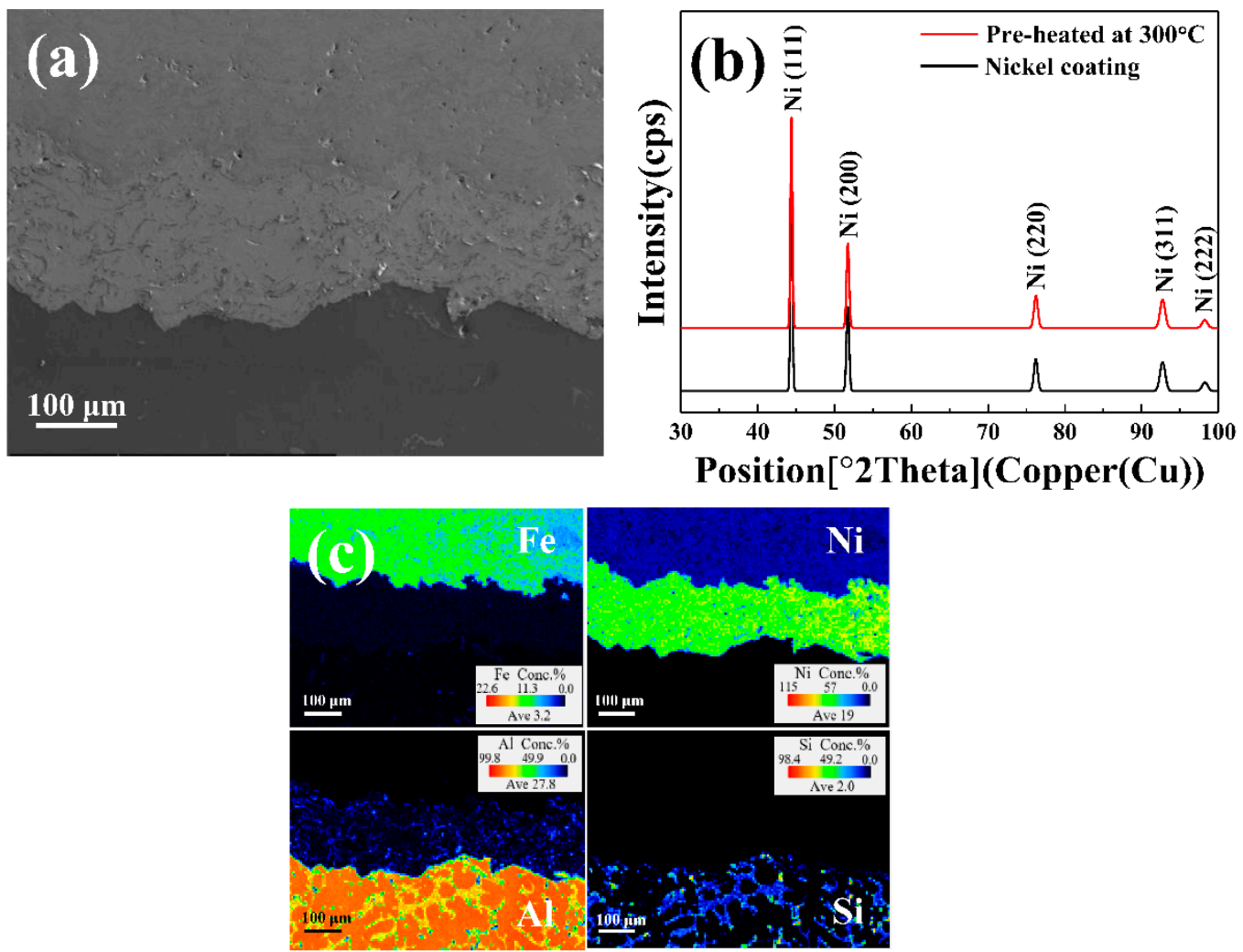

Figure 1. (a) SEM micrographs of the Al/Fe alloys hybrid structure's interface with nickel coating; (b) XRD patterns of nickel coated steel before and after heat treatment at $300^{\circ} \mathrm{C}$; (c) chemical element quantitative maps of (a): $\mathrm{Fe}, \mathrm{Ni}, \mathrm{Al}$, and Si.

Figure 1c shows the chemical element quantitative maps of the Al/Fe alloys hybrid structure with a nickel coating. The boundaries between each metal, along with their morphological characteristics, were apparently discernible and indexed using different colors. No apparent distribution of $\mathrm{Fe}$ and $\mathrm{Ni}$ in the $\mathrm{Al}$ matrix was detected. The $\mathrm{Si}$ elements were located solely at the grain boundary of the Al matrix, and elements in the aluminum alloy did not move into the other metal matrix. These results indicated that the chemical bonding of the interface by elemental diffusion did not occur during dissimilar casting, implying that the nickel coating could theoretically have contributed to the physical bonding of the $\mathrm{Al} / \mathrm{Fe}$ alloys hybrid structure.

\subsection{Effects of Heat Treatment on the Interfacial Microstructures}

Figure 2 shows the interfacial microstructure of the $\mathrm{Al} / \mathrm{Fe}$ alloys hybrid structure heat treated for $1 \mathrm{~h}$ at different solution temperatures, followed by furnace cooling. At a solution temperature of $500{ }^{\circ} \mathrm{C}$ (Figure 2a), the interface of the $\mathrm{Al} / \mathrm{Fe}$ alloys hybrid structure demonstrated a similar microstructure to the as-cast condition without chemical bonding, and no intermetallic phase was formed in the $\mathrm{Al}$ matrix. When the solution temperature increased to $530{ }^{\circ} \mathrm{C}$, the diffusion of atoms at the interface resulted in an intermetallic layer (Figure $2 \mathrm{~b}$ ). The nickel diffused into the $\mathrm{Al}$ matrix, and this led to formation of the intermetallic phase, due to the low solubility of nickel in aluminum [23]. There were no intermetallic phases in the $\mathrm{Al}$ matrix; however, as in the as-cast and $500{ }^{\circ} \mathrm{C}$ solution temperature conditions. Therefore, the temperature at which the inter-diffusion of atoms begins to occur at the interface is approximately $530^{\circ} \mathrm{C}$. When the solution temperature increased to $550{ }^{\circ} \mathrm{C}$, the intermetallic phases at the interface formed a continuous layer and the thickness of the intermetallic layer increased significantly (Figure 2d). The chemical 
bonding that formed at the interface under this particular heat treatment condition was superior. The parabolic law correlates the solution temperature with the growth of the intermetallic layer [24-26], and is expressed as follows:

$$
\begin{gathered}
X=K t^{1 / 2} \\
K=K_{0} \exp \left(-\frac{Q}{R T}\right)
\end{gathered}
$$

where $X$ is the intermetallic layer thickness, $t$ is the heat treatment time, $K$ is the coefficient of diffusion, $K_{0}$ is the diffusion constant, $Q$ is the activation energy for intermetallic phase growth, $T$ is the absolute solution temperature, and $R$ is the gas constant. According to Equations (1) and (2), the solution temperature and diffusion coefficient are proportional, implying that an increase in solution temperature promotes the diffusion of atoms at the interface.

Figure 2c,e show the SEM micrographs of the intermetallic layers created at the interface, at different solution temperatures. Table 3 shows the results of the compositional analysis of the intermetallic layers formed at 530 and $550{ }^{\circ} \mathrm{C}$. The compositions of the intermetallic layer after heat treatment were $\mathrm{Al}_{3} \mathrm{CuNi} / \mathrm{Al}_{3} \mathrm{Ni}$ at $530^{\circ} \mathrm{C}$, and $\mathrm{NiAl} / \mathrm{Al}_{3} \mathrm{Ni}$ at $550{ }^{\circ} \mathrm{C}$. Thus, composition of the intermetallic layer varied with solution treatment temperature. The types of intermetallic layers formed through heat treatment were related to the ratio of diffused atoms. The higher solution temperature caused greater diffusion at the interface, affecting the types of intermetallic phase, which were determined by the $\mathrm{Ni}: \mathrm{Cu}$ ratio in the $\mathrm{Cu}$-containing $\mathrm{Al}$ matrix. As the $\mathrm{Ni}: \mathrm{Cu}$ ratio increased, a nickel-bearing phase formed in the sequence of $\gamma-\mathrm{Al}_{7} \mathrm{Cu}_{4} \mathrm{Ni}, \delta-\mathrm{Al}_{3} \mathrm{CuNi}$, and $\varepsilon-\mathrm{Al}_{3} \mathrm{Ni}$ [27]. Therefore, depending on the solution temperature, the intermetallic layer at the interface primarily comprised $\delta-\mathrm{Al}_{3} \mathrm{CuNi}\left(\right.$ at $\left.530{ }^{\circ} \mathrm{C}\right)$, or $\varepsilon-\mathrm{Al}_{3} \mathrm{Ni}\left(\right.$ at $550{ }^{\circ} \mathrm{C}$ ).

Table 3. The qualitative analysis of the intermetallic layer corresponding to the points in Figure 2c,e.

\begin{tabular}{ccccccccc}
\hline \multirow{2}{*}{ Temperature $\left({ }^{\circ} \mathbf{C}\right)$} & \multirow{3}{*}{ Number } & \multicolumn{9}{c}{ Compositions (at.\%) } & \multirow{2}{*}{ Inference Component } \\
\cline { 3 - 7 } & 1 & $\mathbf{A l}$ & $\mathbf{F e}$ & $\mathbf{N i}$ & $\mathbf{C u}$ & $\mathbf{S i}$ & \\
\hline \multirow{3}{*}{530} & 2 & 72.28 & - & 27.72 & - & - & $\mathrm{Al}_{3} \mathrm{CuNi}$ \\
& 3 & 74.36 & - & 25.64 & - & - & $\mathrm{Al}_{3} \mathrm{Ni}$ \\
& 4 & 58.72 & - & 21.33 & 18.98 & - & $\mathrm{Al}_{3} \mathrm{Ni}$ \\
& 5 & 47.77 & - & 48.47 & - & 3.76 & $\mathrm{Al}_{3} \mathrm{CuNi}$ \\
\hline \multirow{2}{*}{530} & 6 & 73.84 & - & 26.16 & - & - & $\mathrm{Nl}_{3} \mathrm{Ni}$ \\
\hline
\end{tabular}

Figure 3a shows the changes in thickness of the intermetallic layer, at different solution treatment temperatures and annealing times. Heat treatment at $500{ }^{\circ} \mathrm{C}$ for $1 \mathrm{~h}$ and $3 \mathrm{~h}$ did not generate an intermetallic layer. The thickness of the layer formed after $8 \mathrm{~h}$ was approximately $10 \mu \mathrm{m}$, which was thinner than that for other solution treatment temperatures. The intermetallic layer formed at $530^{\circ} \mathrm{C}$ continuously increased until $8 \mathrm{~h}$, but remained thinner than the layer formed at $550{ }^{\circ} \mathrm{C}$. After heat treatment at $550{ }^{\circ} \mathrm{C}$ for $1 \mathrm{~h}$, the intermetallic layer at the interface was continuous and notably thicker than that for the other temperatures. At this heat treatment temperature, and compared with other temperatures, the thickness of the intermetallic layer increased sharply with heat treatment time. Hence, the solution temperature was determined to significantly promote the formation of thick and continuous intermetallic layers. The optimal solution temperature for the chemical bonding of the $\mathrm{Al} / \mathrm{Fe}$ alloys hybrid structure was $550{ }^{\circ} \mathrm{C}$. 


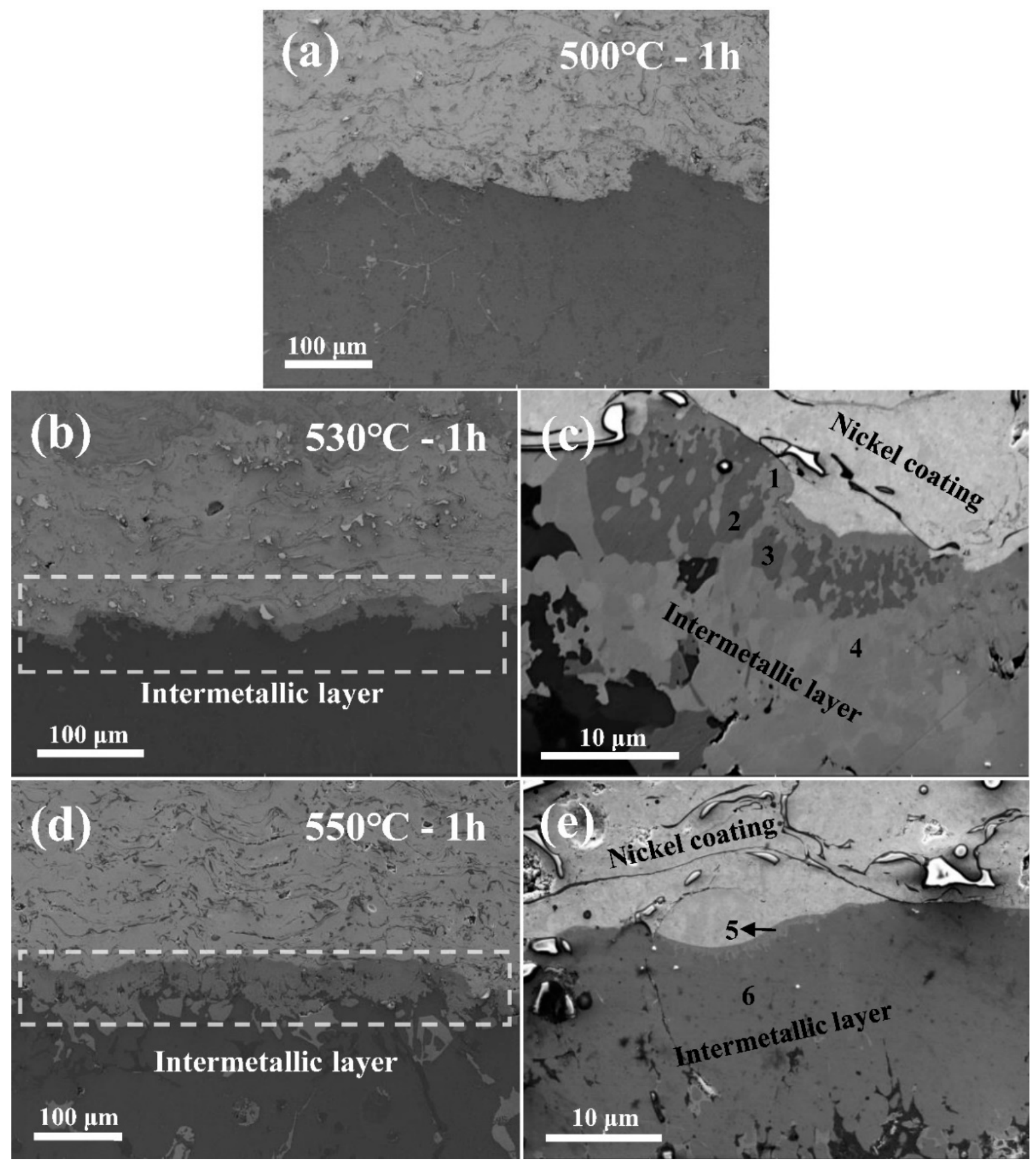

Figure 2. SEM micrographs of the $\mathrm{Al} / \mathrm{Fe}$ alloys hybrid structure's interface under different solution temperatures followed by furnace cooling; (a) $500{ }^{\circ} \mathrm{C},(\mathbf{b}, \mathbf{c}) 530^{\circ} \mathrm{C}$, and (d,e) $550{ }^{\circ} \mathrm{C}$.

Figure $3 \mathrm{~b}$ shows the EPMA line mapping results of the Al/Fe alloys hybrid structure's interface, after heat treatment at $550{ }^{\circ} \mathrm{C}$. The diffusion of $\mathrm{Ni}$ and $\mathrm{Al}$ elements across the interface was evident, implying successful chemical bonding between the nickel and the aluminum following heat treatment. Furthermore, these results confirmed that the Fe elements from the steel did not actively diffuse into the Al matrix during the heat treatment process. This was due to the nickel coating. 
(a)

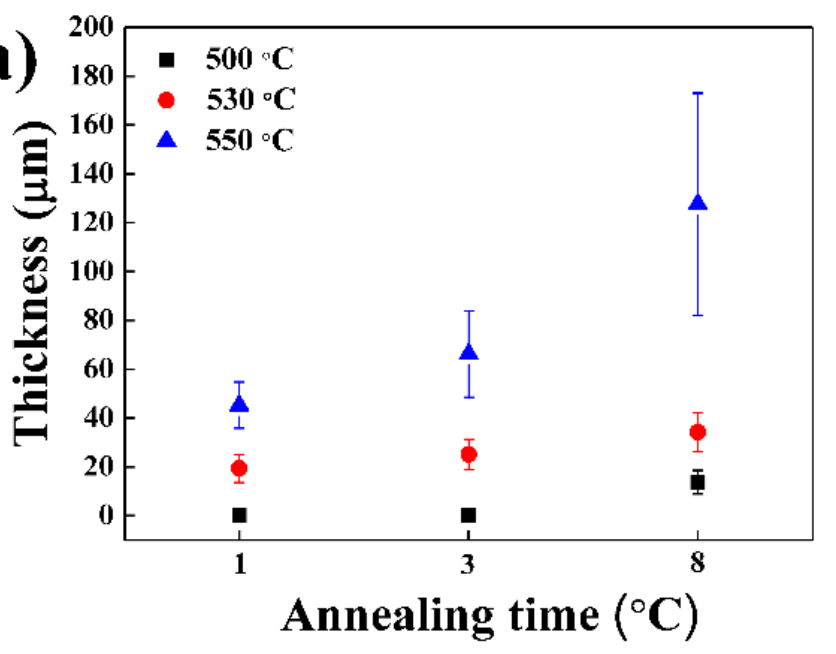

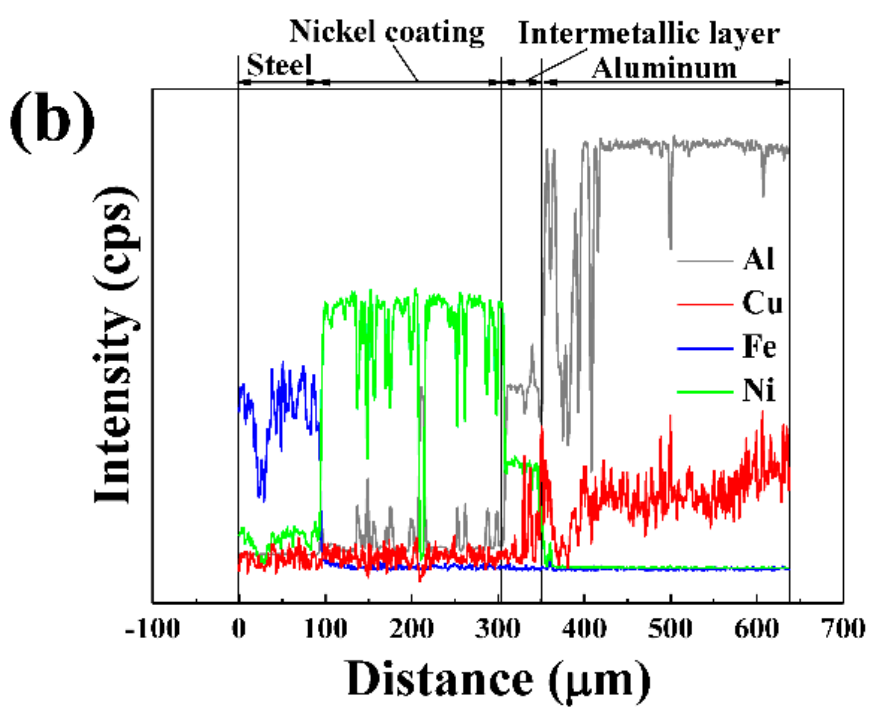

Figure 3. (a) The quantitative analysis of intermetallic layer thickness under different solution temperature and annealing times and (b) electron probe X-ray microanalyzer (EPMA) line mapping of the Al/Fe alloys hybrid structure's interface under $550{ }^{\circ} \mathrm{C}$ heat treatment, followed by furnace cooling.

Although the intermetallic layer thickness increased with increasing the solution treatment time and temperature, excessively long heat treatment times decreased the bonding strength of the $\mathrm{Al} / \mathrm{Fe}$ alloys hybrid structure. Long-term heat treatment for $8 \mathrm{~h}$ caused the formation of cracks between the intermetallic layer and the aluminum substrate (Figure 4). We believe that there are two main reasons for this. First, the large difference in the coefficients of thermal expansion (CTE) between the aluminum alloy and the intermetallic layer induces excessive thermal stress, sufficient to form cracks at the interface $[26,28,29]$. The condition under which the crack is generated at the interface between the intermetallic layer and the aluminum alloy, is described by Equation (3) [30]:

$$
\Delta T=\frac{16}{3(1+v)} \frac{x^{2}}{a^{2}} \frac{1}{\Delta \alpha}
$$

where $\Delta T$ is the temperature change at which cracking and detachment are initiated at the interface between the aluminum alloy and the intermetallic phase, $x$ is the thickness of the intermetallic layer, $\Delta \alpha$ is the difference in the coefficients of thermal expansion between the aluminum alloy and intermetallic phase, $v$ is Poisson's ratio, and a is the length of the crack created at the interface as the temperature decreases during cooling. Among these parameters, $v$ and $\Delta \alpha$ are intrinsic properties of the material and $\Delta T$ is a constant determined by heat treatment. Resulting from Equation (3), an increase in the intermetallic layer thickness induces a growth in the crack length [28]. Excessive heat treatment, including extreme solution temperatures and/or times, can trigger cracks at the interface, resulting in a decline in the bonding strength.

Second, the Kirkendall effect [31] generated by the difference in the diffusion ratio of the metals, causes the detachment of the intermetallic layer and $\mathrm{Al}$ substrate from the interface [32]. This phenomenon can trigger the formation of voids and pores at the interface, which assists detachment of the interface [28].

Figure 5 shows that the Ni elements diffused in the interface during heat treatment at $550{ }^{\circ} \mathrm{C}$ also contributed to the precipitation of the nickel-bearing phase in the $\mathrm{Al}$ matrix, in accordance with the distance from the interface. The EDS results (Table 4; Figure 5a,c) indicated that the type of intermetallic phases generated in the $\mathrm{Al}$ matrix near the interface differed between the as-cast and $550^{\circ} \mathrm{C}$ heat treatment conditions. However, as indicated in Figure $5 b, d$, the identical types of intermetallic phases in the $\mathrm{Al}$ matrix away from interface were formed, regardless of the heat treatment. This implies that the nickel diffusion during 
the heat treatment process also affected the type of intermetallic phases in the $\mathrm{Al}$ matrix near the interface. The nickel reacted with the $\mathrm{Al}, \mathrm{Cu}$, and $\mathrm{Fe}$ atoms to precipitate the nickelbearing phase, which was stable in this system. In particular, the types of phases containing Fe were different in the as-cast and $550{ }^{\circ} \mathrm{C}$ heat treatment conditions. Generally, the $\beta$ $\mathrm{Al}_{4.5} \mathrm{FeSi}$ formed by the presence of $\mathrm{Fe}$ in $\mathrm{Al}-\mathrm{Si}-\mathrm{Cu}$ alloys was presented as needle-shaped particles that causes stress concentration, and was weakly bonded to the $\mathrm{Al}$ matrix. This phase therefore compromises the mechanical properties of the alloys [33,34]. Accordingly, the presence of this phase at the interface could reduce the bonding strength of the $\mathrm{Al} / \mathrm{Fe}$ alloys hybrid structure. However, the nickel coating at the interface prevented the diffusion of Fe into the $\mathrm{Al}$ matrix, and the diffused $\mathrm{Ni}$ atoms can also act as Fe absorbers. Thus, the formation of the $\beta-\mathrm{Al}_{4.5} \mathrm{FeSi}$ phase was suppressed, and instead the formation of $\mathrm{Al}_{9} \mathrm{FeNi}$ was promoted $[27,35]$. Due to the inability of nickel to diffuse into the Al matrix far from the interface during heat treatment, $\mathrm{Al}_{2} \mathrm{Cu}$ and $\beta-\mathrm{Al}_{4.5} \mathrm{FeSi}$ compounds were instead formed. (Figure $5 \mathrm{~d}$ ). The nickel-bearing phase (which possesses good thermal stability at elevated temperatures) that was formed at the $\alpha-\mathrm{Al}$ grain boundary, improved the mechanical properties of the aluminum alloy at elevated temperatures. As mentioned above, among the nickel-bearing phases, the strip-like $\delta-\mathrm{Al}_{3} \mathrm{CuNi}$ particularly enhance the mechanical properties of aluminum alloys at elevated temperatures [36].
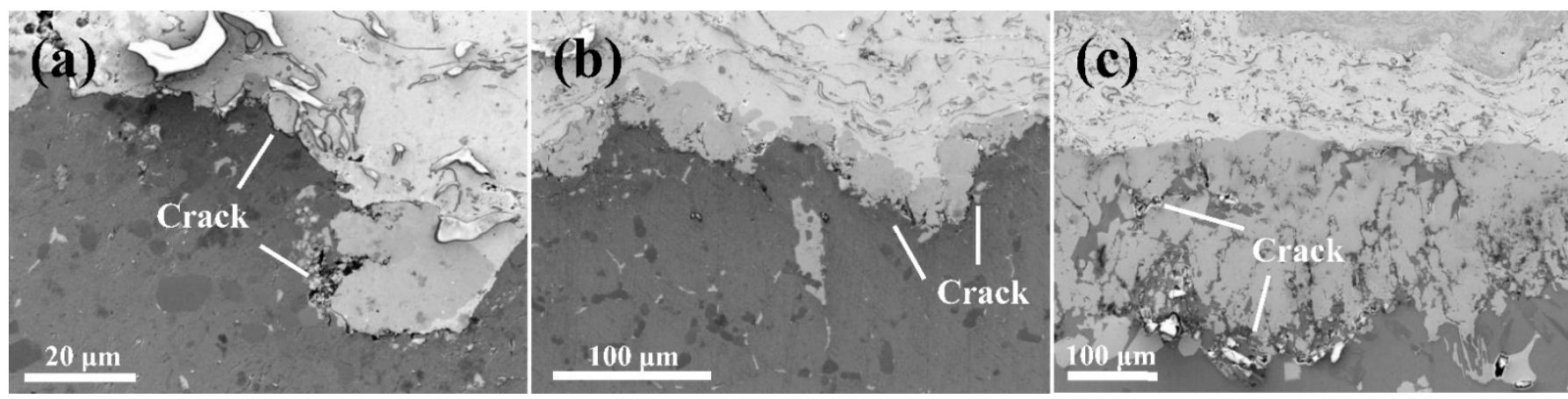

Figure 4. SEM micrographs of the $\mathrm{Al} / \mathrm{Fe}$ alloys hybrid structure's interface under excessive heat treatment for $8 \mathrm{~h}$; (a) $500{ }^{\circ} \mathrm{C}$, (b) $530{ }^{\circ} \mathrm{C}$, and (c) $550{ }^{\circ} \mathrm{C}$.

Table 4. The qualitative analysis of the intermetallic phase corresponding to the points in Figure 5.

\begin{tabular}{ccccccc}
\hline \multirow{2}{*}{ Number } & \multicolumn{5}{c}{ Compositions (at.\%) } & \multirow{2}{*}{ Inference Component } \\
\cline { 2 - 5 } & $\mathbf{A l}$ & $\mathbf{F e}$ & $\mathbf{N i}$ & $\mathbf{C u}$ & $\mathbf{S i}$ & \\
\hline 1 & 65.73 & - & - & 34.27 & - & $\mathrm{Al}_{2} \mathrm{Cu}$ \\
2 & 66.36 & 16.3 & - & - & 17.34 & $\mathrm{Al}_{4.5} \mathrm{FeSi}$ \\
3 & 70.45 & 13.14 & - & 1.32 & 15.08 & $\mathrm{Al}_{4.5} \mathrm{FeSi}$ \\
4 & 66.64 & - & - & 33.36 & - & $\mathrm{Al}{ }_{2} \mathrm{Cu}$ \\
5 & 70.98 & 14.81 & - & - & 14.21 & $\mathrm{Al}_{4.5} \mathrm{FeSi}$ \\
6 & 70.71 & 4.94 & 18.88 & - & 5.47 & $\mathrm{Al}_{9} \mathrm{FeNi}$ \\
7 & 58.28 & - & 20.55 & 21.18 & - & $\mathrm{Al}_{3} \mathrm{CuNi}$ \\
8 & 70.04 & 5.29 & 18.93 & - & 5.75 & $\mathrm{Al}_{9} \mathrm{FeNi}$ \\
9 & - & - & - & - & 100 & $\mathrm{Si} \mathrm{particle}$ \\
10 & 57.63 & - & 22.28 & 20.08 & - & $\mathrm{Al}_{3} \mathrm{CuNi}$ \\
11 & 68.46 & - & - & 30.35 & 1.19 & $\mathrm{Al}_{2} \mathrm{Cu}$ \\
12 & - & - & - & - & 100 & $\mathrm{Si} \mathrm{particle}_{10}$ \\
13 & 67.42 & 17.06 & - & - & 15.53 & $\mathrm{Al}_{4.5} \mathrm{FeSi}$ \\
14 & 70.2 & 13.32 & - & - & 16.48 & $\mathrm{Al}_{4.5} \mathrm{FeSi}$ \\
\hline
\end{tabular}




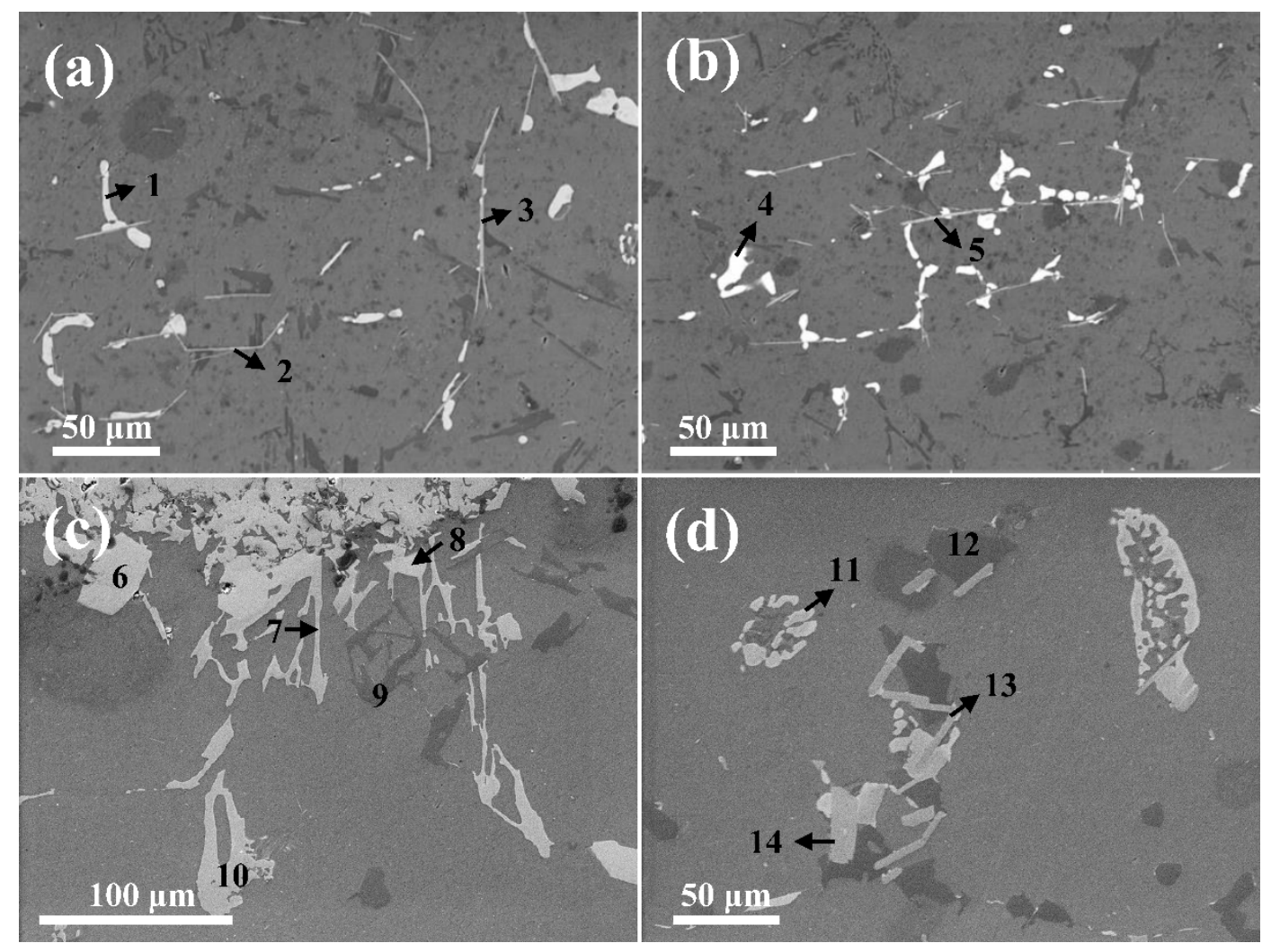

Figure 5. SEM micrographs of the intermetallic phases in the $\mathrm{Al}$ matrix according to distance from the interface under as-cast and $550{ }^{\circ} \mathrm{C}$ heat treatment conditions; (a) as-cast (near interface), (b) as-cast (far from interface), (c) $550{ }^{\circ} \mathrm{C}$ heat treatment (near interface), and (d) $550{ }^{\circ} \mathrm{C}$ heat treatment (far from interface).

The different types of nickel-bearing phases produced by nickel diffusion at the interface and Al matrix could be explained by the results of the thermodynamic calculations, which reveal the equilibrium nickel concentration range of each phase. Figure $6 a, b$ show calculated phase diagrams of the A319 (Al-Si-Cu-Mg-Fe) alloy system at different nickel contents $(0-10 \%)$. The red line indicates the specific nickel concentration that affected the transformation of the nickel-bearing phase. Table 5 presents the nickel-bearing phase transformation stages of this alloy system under equilibrium conditions, at each nickel concentration range. The results show that the types of nickel-bearing phases and nickel concentrations in the alloy system were interdependent, and that based on the nickel content ranges, the equilibrium phases of the system differed. At nickel contents above $5.14 \%, \varepsilon-\mathrm{Al}_{3} \mathrm{Ni}$ starts to form in this system, but then transforms to $\delta-\mathrm{Al}_{3} \mathrm{CuNi}$, until the nickel concentration reached $6.16 \%$. In this reaction, the liquids reacted with $\varepsilon-\mathrm{Al}_{3} \mathrm{Ni}$ to produce $\delta-\mathrm{Al}_{3} \mathrm{CuNi}$. Therefore, for $\varepsilon-\mathrm{Al}_{3} \mathrm{Ni}$ to be stable in this system, the nickel concentration must exceed $6.16 \%$; this is the minimum amount of nickel required to diffuse into the $\mathrm{Al}$ matrix, and form $\varepsilon-\mathrm{Al}_{3} \mathrm{Ni}$ during heat treatment. At critically low nickel concentrations, the $\mathrm{Al}$ and $\mathrm{Cu}$ atoms combined with $\mathrm{Ni}$ to form $\delta-\mathrm{Al}_{3} \mathrm{CuNi}$, and attained equilibrium in the absence of $\varepsilon-\mathrm{Al}_{3} \mathrm{Ni}$, until the nickel concentration reached $5.14 \%$. The $\delta-\mathrm{Al}_{3} \mathrm{CuNi}$ remained in equilibrium over a wide range of nickel concentrations because the A319 alloy system contained significant amounts of $\mathrm{Cu}$. It should be noted that $\varepsilon-\mathrm{Al}_{3} \mathrm{Ni}$ and $\delta-\mathrm{Al}_{3} \mathrm{CuNi}$ attained equilibrium at different ranges of nickel concentration. The analysis of the phase diagram indicated that the $\mathrm{Ni}: \mathrm{Cu}$ ratio determined which nickel-bearing phase would form in this alloy system. Although $\delta-\mathrm{Al}_{3} \mathrm{CuNi}$ attained the equilibrium state at almost every nickel concentration range, $\varepsilon-\mathrm{Al}_{3} \mathrm{Ni}$ was solely formed when the $\mathrm{Ni} \mathrm{Cu}$ ratio in the alloy system exceeded 2.2. These results indicate that the formation of the nickel-bearing phases, influenced by the solution temperature and proximity to the interface, can vary. The $\mathrm{T}-\mathrm{Al}{ }_{9} \mathrm{FeNi}$ attained the equilibrium state over a wide range of nickel concentrations 
in this system; when the nickel concentration surpassed $0.15 \%, \mathrm{~T}-\mathrm{Al}_{9} \mathrm{FeNi}$ started to form; however, it did not attain equilibrium during solidification until the $0.73 \%$. On the range of $0.73 \%$ to $5.14 \%$ nickel, $\mathrm{T}-\mathrm{Al}_{9} \mathrm{FeNi}$ formed through the peritectic reaction between the liquids and $\beta-\mathrm{Al}_{4.5} \mathrm{FeSi}$. Especially, $\beta-\mathrm{Al}_{4.5} \mathrm{FeSi}$ was completely transformed into $\mathrm{T}-\mathrm{Al} 9 \mathrm{FeNi}$ at $2.32 \%$ nickel and above. When the nickel concentration exceeded $5.14 \%$, the $\mathrm{T}-\mathrm{Al}_{9} \mathrm{FeNi}$ phase was formed without the peritectic reaction, while maintaining its equilibrium state as the nickel concentration continued to increase. At this concentration range, Ni reacted with $\mathrm{Fe}$ to selectively form $\mathrm{T}-\mathrm{Al}{ }_{9} \mathrm{FeNi}$, whereas $\beta-\mathrm{Al}_{4.5} \mathrm{FeSi}$ was not formed, confirming the theory that nickel can act as an Fe absorber and effectively suppress the formation of $\beta-\mathrm{Al}_{4.5} \mathrm{FeSi}$ in this system. Since no $\beta-\mathrm{Al}_{4.5} \mathrm{FeSi}$ were observed near the interface of the $\mathrm{Al}$ matrix during the heat treatment process, this theory was confirmed experimentally.
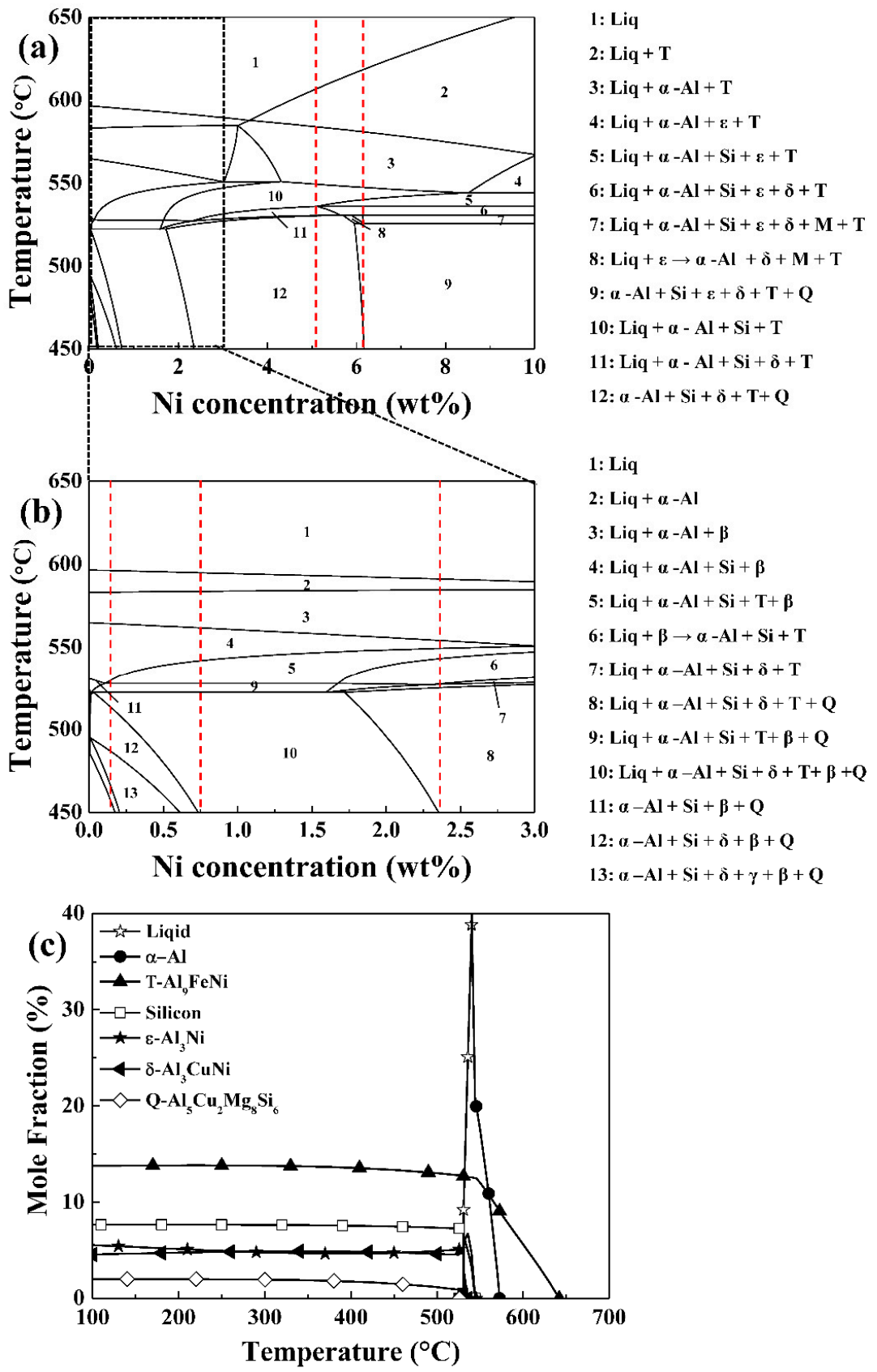

Figure 6. (a,b) Calculated phase diagram of the Al-Si-Cu-Mg-Fe system for different nickel ranges $(0-10 \%)$, and (c) mole fraction of different phases as a temperature function in the Al-7.98Si-2.8Cu$0.64 \mathrm{Mg}-0.74 \mathrm{Fe}-8.62 \mathrm{Ni}$ system. 
Table 5. Nickel-bearing phase transformation of the Al-Si-Cu-Mg-Fe system under equilibrium conditions at different nickel ranges.

\begin{tabular}{|c|c|c|c|c|c|c|}
\hline \multirow{2}{*}{$\begin{array}{c}\text { Nickel Concentration }(=X) \\
X>6.16 \%\end{array}$} & \multicolumn{6}{|c|}{$\begin{array}{l}\text { Nickel-Bearing Phase Transformation of the } \\
\text { Al-Si-Cu-Mg-Fe System under Equilibrium Conditions }\end{array}$} \\
\hline & $\mathrm{L} \rightarrow \mathrm{T}$ & $\mathrm{L} \rightarrow \alpha+\mathrm{T}$ & $\mathrm{L} \rightarrow \alpha+\mathrm{Si}+\mathrm{T}$ & $\mathrm{L} \rightarrow \alpha+\mathrm{Si}+\varepsilon+\mathrm{T}$ & $\mathrm{L} \rightarrow \alpha+\mathrm{Si}+\varepsilon+\delta+\mathrm{T}$ & - \\
\hline $5.14 \%<X<6.16 \%$ & $\mathrm{~L} \rightarrow \mathrm{T}$ & $\mathrm{L} \rightarrow \alpha+\mathrm{T}$ & $\mathrm{L} \rightarrow \alpha+\mathrm{Si}+\mathrm{T}$ & $\mathrm{L} \rightarrow \alpha+\mathrm{Si}+\varepsilon+\delta+\mathrm{T}$ & $\mathrm{L}+\varepsilon \rightarrow \alpha+\mathrm{Si}+\delta+\mathrm{T}$ & - \\
\hline $2.32 \%<X<5.14 \%$ & $\mathrm{~L} \rightarrow \alpha$ & $\mathrm{L} \rightarrow \alpha+\beta$ & $\mathrm{L} \rightarrow \alpha+\mathrm{Si}+\beta$ & $\mathrm{L}+\beta \rightarrow \alpha+\mathrm{Si}+\mathrm{T}+\beta$ & $\mathrm{L}+\beta \rightarrow \alpha+\mathrm{Si}+\mathrm{T}$ & $\mathrm{L} \rightarrow \alpha+\mathrm{Si}+\delta+\mathrm{T}$ \\
\hline $0.73 \%<\mathrm{X}<2.32 \%$ & $\mathrm{~L} \rightarrow \alpha$ & $\mathrm{L} \rightarrow \alpha+\beta$ & $\mathrm{L} \rightarrow \alpha+\mathrm{Si}+\beta$ & $\mathrm{L}+\beta \rightarrow \alpha+\mathrm{Si}+\mathrm{T}+\beta$ & $\mathrm{L} \rightarrow \alpha+\mathrm{Si}+\delta+\beta+\mathrm{T}$ & - \\
\hline $0.15 \%<X<0.73 \%$ & $\mathrm{~L} \rightarrow \alpha$ & $\mathrm{L} \rightarrow \alpha+\beta$ & $\mathrm{L} \rightarrow \alpha+\mathrm{Si}+\beta+\mathrm{T}$ & $\mathrm{L} \rightarrow \alpha+\mathrm{Si}+\delta+\beta$ & - & - \\
\hline $0.15 \%>X$ & $\mathrm{~L} \rightarrow \alpha$ & $\mathrm{L} \rightarrow \alpha+\beta$ & $\mathrm{L} \rightarrow \alpha+\mathrm{Si}+\beta$ & $\mathrm{L} \rightarrow \alpha+\mathrm{Si}+\delta+\beta$ & $\mathrm{L} \rightarrow \alpha+\mathrm{Si}+\delta+\gamma+\beta$ & - \\
\hline
\end{tabular}

Figure $6 \mathrm{c}$ illustrates the mole fractions of different intermetallic phases as a function of temperature in the $\mathrm{Al}-\mathrm{Si}-\mathrm{Cu}-\mathrm{Mg}-\mathrm{Fe}-\mathrm{Ni}$ system containing $8.62 \% \mathrm{Ni}$. Due to the considerable amount of nickel required to form the $\varepsilon-\mathrm{Al}_{3} \mathrm{Ni}$ phase in the $\mathrm{A} 319$ alloy system with high $\mathrm{Cu}$, the mole fraction of the $\varepsilon-\mathrm{Al}_{3} \mathrm{Ni}$ phase started to escalate from above the $6.16 \%$ nickel, and was higher than that of $\delta-\mathrm{Al}_{3} \mathrm{CuNi}$ at $8.62 \%$ nickel. Therefore, for the intermetallic layer comprising the $\varepsilon-\mathrm{Al}_{3} \mathrm{Ni}$ phase to be generated at the interface, more than $8.62 \%$ nickel was required in the $\mathrm{Al}$ matrix during the heat treatment process.

Figure 7 illustrates the interfacial microstructures of the $\mathrm{Al} / \mathrm{Fe}$ alloys hybrid structures observed at different solution temperatures, followed by air cooling. Cracks occurred between the nickel coating layer and the $\mathrm{Al}$ matrix at $500{ }^{\circ} \mathrm{C}$ temperature (Figure 7a). At temperatures of $530{ }^{\circ} \mathrm{C}$ and $550{ }^{\circ} \mathrm{C}$, cracks formed between the intermetallic layer and the $\mathrm{Al}$ matrix, as shown in Figure $7 \mathrm{~b}, \mathrm{c}$. Hence, cracks occurred at the interface due to air cooling, regardless of the heat treatment temperature. We believe this was due to a large thermal gradient created by air cooling. Thermal stress during heat treatment is created by the difference in CTE between the two materials in contact at the interface [29]. The CTEs in the two materials in the hybrid materials are different, resulting in disparate contraction rates during rapid cooling. This disparity caused severe thermal shock at the interface, which in turn escalated the thermal stress applied to the interface. The results show that furnace cooling was vastly superior to air cooling for promotion of superior chemical bonding at the interface of the $\mathrm{Al} / \mathrm{Fe}$ alloys hybrid structure. Furthermore, the $\mathrm{Al}_{3} \mathrm{Ni}$ phase was precipitated in the $\mathrm{Al}$ matrix close to the interface of the $\mathrm{Al} / \mathrm{Fe}$ alloys hybrid structure, after heat treatment at $550{ }^{\circ} \mathrm{C}$ followed by air-cooling (Figure $7 \mathrm{~d}$ ). However, as shown in Figure $5 \mathrm{c}$, which shows the furnace cooling conditions after the same heat treatment process, $\mathrm{Al}_{3} \mathrm{Ni}$ was not observed in the $\mathrm{Al}$ matrix, indicating that the cooling rate also affects the type of intermetallic phase formed. Under these particular heat treatment conditions, the $\mathrm{Al}_{3} \mathrm{Ni}$ that was formed in the $\mathrm{Al}$ matrix, transformed into $\mathrm{Al}_{3} \mathrm{CuNi}$ during the furnace cooling stage. In contrast, under a faster air-cooling rate, the reaction could not be completed and $\mathrm{Al}_{3} \mathrm{Ni}$ was precipitated in the $\mathrm{Al}$ matrix instead.

Figure 8 summarizes the chemical bonding mechanism of the $\mathrm{Al} / \mathrm{Fe}$ alloys hybrid structure with nickel coating under optimized heat treatment conditions. During the $550{ }^{\circ} \mathrm{C}$ heat treatment process, inter-diffusion of $\mathrm{Al}$ and $\mathrm{Ni}$ occurred at the interface of the $\mathrm{Al} / \mathrm{Fe}$ alloys hybrid structure during chemical bonding, whereas the Fe elements were obstructed by the nickel coating and did not diffuse into the $\mathrm{Al}$ matrix (Figure 8a). Figure $8 \mathrm{~b}$ shows the intermetallics formed by the diffusion of elements at the interface and in the Al matrix during the heat treatment process. The type of intermetallics was dependent on the $\mathrm{Ni}: \mathrm{Cu}$ ratio and generated a continuous layer at the interface. Finally, Figure $8 \mathrm{c}$ shows that the precipitated $\mathrm{Al}_{3} \mathrm{Ni}$ in the $\mathrm{Al}$ matrix transformed into $\mathrm{Al}_{3} \mathrm{CuNi}$ during the furnace cooling process, and superior chemical bonding was achieved at the interface. 


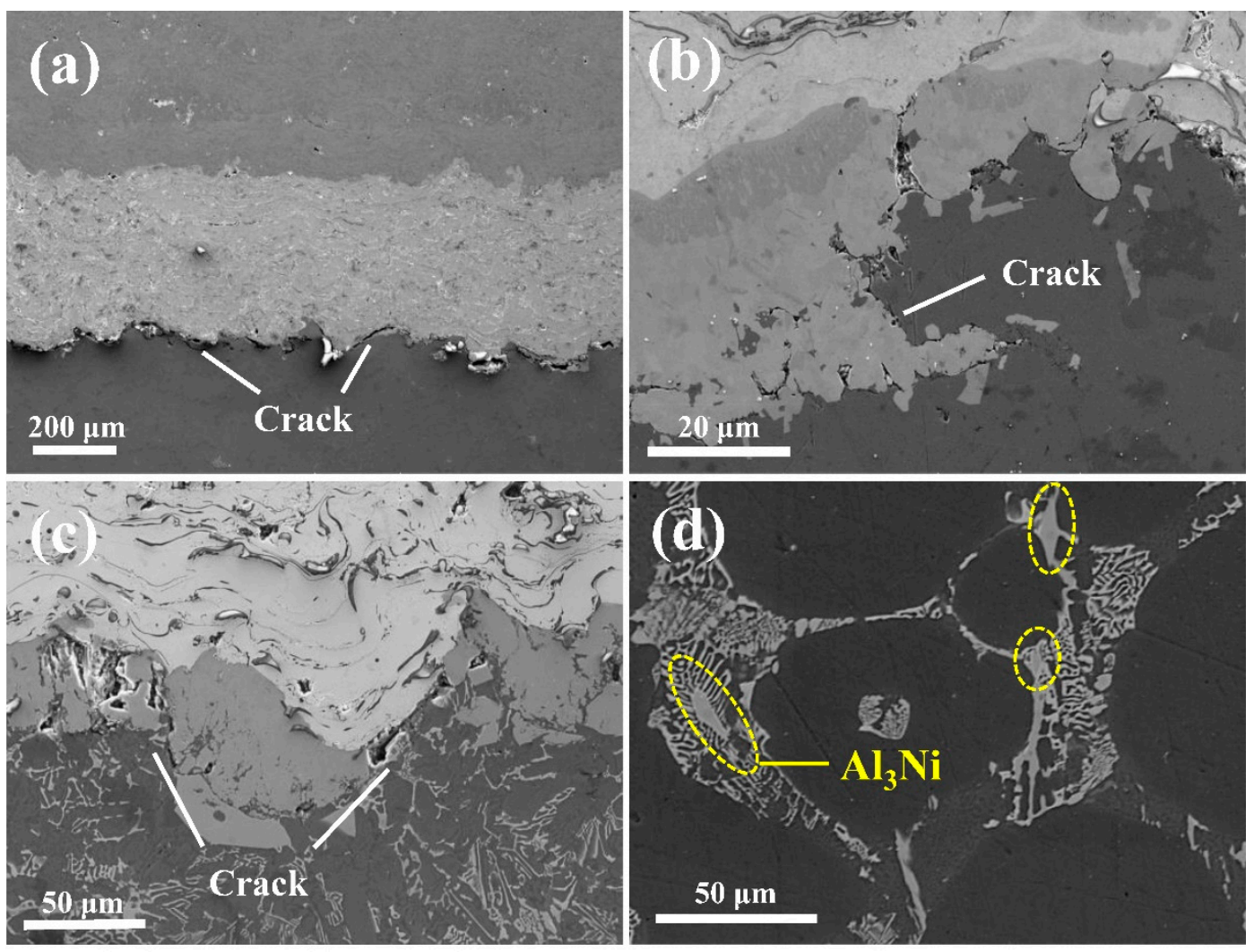

Figure 7. (a-c) SEM micrographs of the $\mathrm{Al} / \mathrm{Fe}$ alloys hybrid structure's interface under different solution temperature, followed by air cooling; (a) $500{ }^{\circ} \mathrm{C}$, (b) $530{ }^{\circ} \mathrm{C}$, and (c) $550{ }^{\circ} \mathrm{C}$. (d) The precipitated $\mathrm{Al}_{3} \mathrm{Ni}$ at the matrix after $550^{\circ} \mathrm{C}$ heat treatment, followed by air cooling.

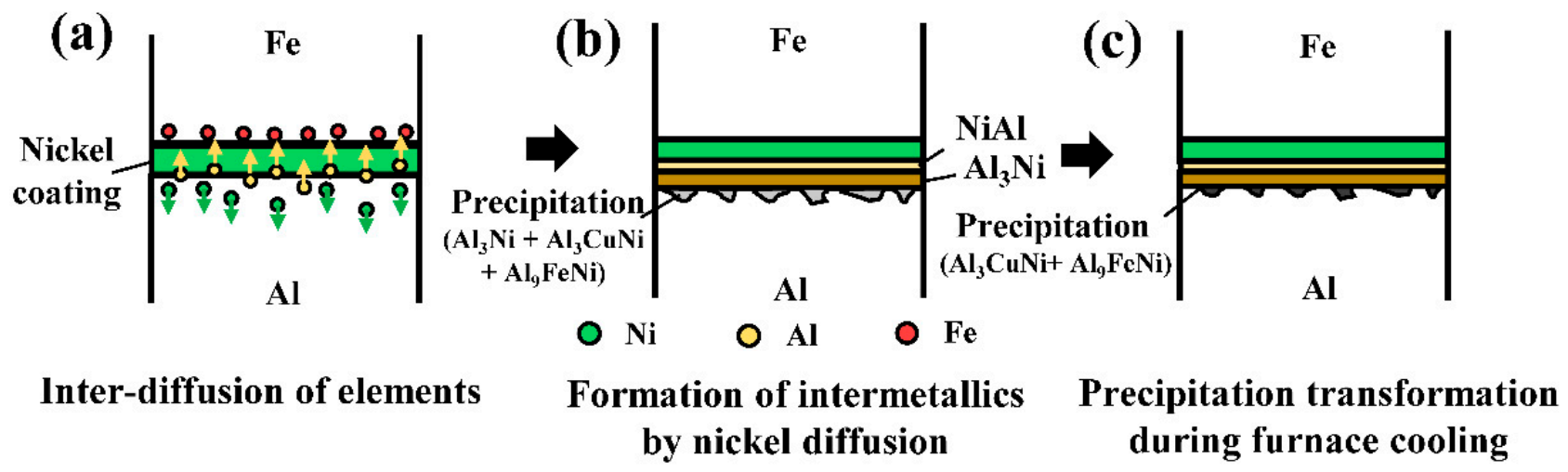

Figure 8. Schematic illustration of the chemical bonding process of the $\mathrm{Al} / \mathrm{Fe}$ alloys hybrid structure under optimized heat treatment condition.

\subsection{Micro-Hardness Distribution in the Al/Fe Alloys Hybrid Structure}

Under optimized heat treatment conditions, multiple layers were formed at the $\mathrm{Al} / \mathrm{Fe}$ alloys hybrid structure's interface. The effects of heat treatment and elemental diffusion on the hardness of each layer and matrix were analyzed using the Vickers hardness test. Figure 9 illustrates the microhardness distribution across the Al/Fe alloys hybrid structure interface for as-cast and optimized heat treatment conditions. The hardness of the steel matrix and the nickel coating layer did not change after the heat treatment. The intermetallic layer, composed of the hard and brittle nickel-bearing phase, exhibited the highest hardness in the $\mathrm{Al} / \mathrm{Fe}$ alloys hybrid structure. Furthermore, it was confirmed that heat treatment significantly reduced the hardness of the Al matrix (40\%, from $100 \mathrm{HV}$ to $60 \mathrm{HV})$. We 
believe that the heat treatment parameters, such as $550{ }^{\circ} \mathrm{C}$ solution temperature and furnace cooling, were sufficient for grains to develop in the $\mathrm{Al}$ matrix, thus impacting its hardness [37]. Furthermore, the hardness of the $\mathrm{Al}$ matrix remained similar, regardless of the distance from the interface. In the microstructural analysis, the intermetallic phases that formed differed depending on the distance from the interface, implying that the nickel-bearing phase created by the diffusion of nickel did not affect the hardness of the $\mathrm{Al}$ matrix at room temperature. The effect of artificial aging (AG) was investigated for alleviating the hardness reduction of the Al matrix. The artificial aging process only affected the hardness of the $\mathrm{Al}$ matrix in the $\mathrm{Al} / \mathrm{Fe}$ alloys hybrid structure; however, the effect was dependent on the distance from the interface. The hardness of the $\mathrm{Al}$ matrix far from the interface increased by approximately 35\% (from $60 \mathrm{HV}$ to $93 \mathrm{HV}$ ), whereas that of the $\mathrm{Al}$ matrix near the interface did not increase. During artificial aging, the $\mathrm{Al}-\mathrm{Si}$ $\mathrm{Cu}$ aluminum alloy precipitates nanosized $\theta-\mathrm{Al}_{2} \mathrm{Cu}$ in the $\mathrm{Al}$ matrix. The precipitation hardening effect from these precipitates increased the hardness of the Al matrix far from the interface [38]; however, the hardness of the $\mathrm{Al}$ matrix near the interface did not increase. Thus, precipitation hardening did not occur near the interface, even after artificial aging. The explanation for this could involve diffusion of nickel. The nickel moved into the Al matrix and combined with $\mathrm{Al}$ and $\mathrm{Cu}$ atoms to form the nickel-bearing phase. During this reaction, the $\mathrm{Cu}$ atoms in the $\mathrm{Al}$ matrix near the interface were depleted. Therefore, the $\theta-\mathrm{Al}_{2} \mathrm{Cu}$ phase could not form and precipitation hardening did not occur [27]. To summarize, the nickel that diffused into the $\mathrm{Al}$ matrix contributed to the formation of the nickel-bearing phase but interfered with the precipitation hardening process.

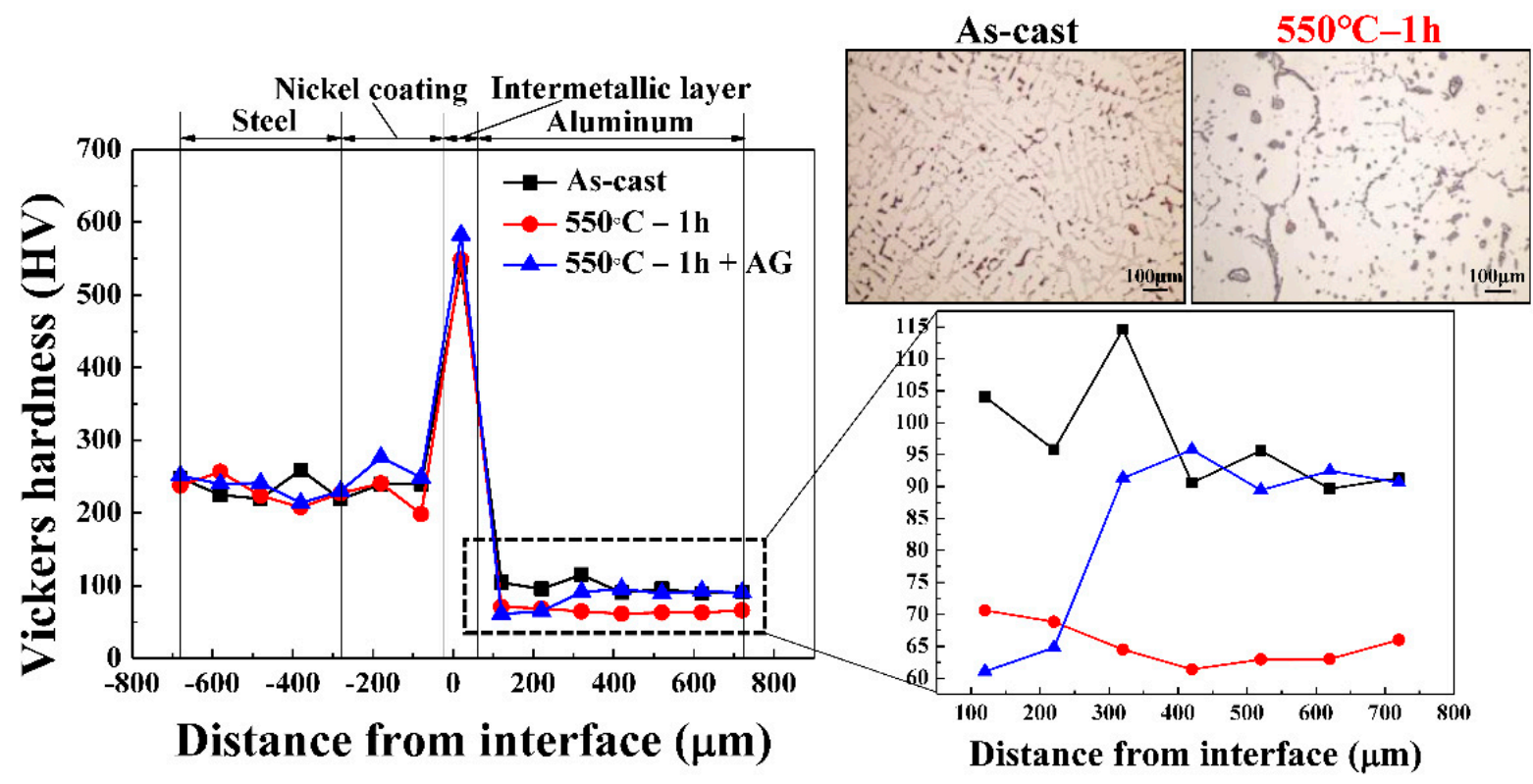

Figure 9. Micro-hardness distribution across the $\mathrm{Al} / \mathrm{Fe}$ alloys hybrid structure's interface under as-cast and heat treatment conditions; AG: Artificial aging.

\section{Conclusions}

This study investigated a methodology to improve the interfacial bonding between aluminum and ferrous alloys, which has previously been difficult. Our results indicated that the application of a nickel coating, combined with an optimized heat treatment process, effectively enhanced the interfacial bonding of the $\mathrm{Al} / \mathrm{Fe}$ alloys hybrid structure.

(1) The $\mathrm{Al} / \mathrm{Fe}$ alloys hybrid structure was fabricated using a dissimilar casting process and utilized a nickel coating on steel. The interface of the $\mathrm{Al} / \mathrm{Fe}$ alloys hybrid structure with the nickel coating was free from defects and exhibited improved mechanical bonding. However, chemical bonding did not occur at the interface during dissimilar casting. 
(2) The heat treatment process at $550{ }^{\circ} \mathrm{C}$, followed by furnace cooling, improved the interfacial bonding through the formation of a continuous and relatively thick intermetallic layer. However, an excessively long heat treatment and a fast cooling rate caused cracks at the interface.

(3) Depending on the solution temperature, different types of nickel-bearing phases formed at the interface of the $\mathrm{Al} / \mathrm{Fe}$ alloys hybrid structure and in the $\mathrm{Al}$ matrix. The types of these phases were determined by Ni:Cu ratios. This ratio was affected by the heat treatment temperature.

(4) The nickel coating prevented the diffusion of Fe elements between the steel matrix and the $\mathrm{Al}$ matrix during heat treatment. Additionally, the diffused nickel, which acted as an Fe absorber during heat treatment, promoted the formation of $\mathrm{T}-\mathrm{Al}{ }_{9} \mathrm{FeNi}$ (called the nickel-bearing phase), instead of $\beta-\mathrm{Al}_{4.5} \mathrm{FeSi}$.

(5) The optimized heat treatment conditions for the chemical bonding of the $\mathrm{Al} / \mathrm{Fe}$ alloys hybrid structure's interface induced a $40 \%$ decrease (from $100 \mathrm{HV}$ to $60 \mathrm{HV}$ ) in the hardness of the Al matrix, whereas artificial aging increased the Al matrix hardness by $35 \%$ (from $63 \mathrm{HV}$ to $90 \mathrm{HV}$ ), through precipitation hardening. Artificial aging had no effect in the $\mathrm{Al}$ matrix near the interface, however, due to the diffusion of nickel.

Author Contributions: Conceptualization, G.M. and E.L.; validation, G.M. and E.L.; formal analysis, G.M. and E.L.; investigation, G.M. and E.L.; data curation. G.M.; methodology, G.M.; visualization, G.M.; resources, G.M.; writing—original draft preparation, G.M.; supervision, E.L.; project administration, E.L.; funding acquisition, E.L.; writing-review and editing, E.L. All authors have read and agreed to the published version of the manuscript.

Funding: This research was supported by the National Research Foundation of Korea (NRF) granted by the Korean Government (NRF-2019R111A3A01062863).

Institutional Review Board Statement: Not applicable.

Informed Consent Statement: Not applicable.

Data Availability Statement: The data presented in this study are available on request from the corresponding author.

Conflicts of Interest: The authors declare no conflict of interest.

\section{References}

1. Grosselle, F.; Timelli, G.; Bonollo, F. Doe applied to microstructural and mechanical properties of Al-Si-Cu-Mg casting alloys for automotive applications. Mater. Sci. Eng. A 2010, 527, 3536-3545. [CrossRef]

2. Liu, Y.; Bian, X.; Zhang, K.; Yang, C.; Feng, L.; Kim, H.S.; Guo, J. Interfacial microstructures and properties of aluminum alloys/galvanized low-carbon steel under high-pressure torsion. Mater. Des. 2014, 64, 287-293. [CrossRef]

3. Lee, E.; Mishra, B. Effect of solidification cooling rate on mechanical properties and microstructure of Al-Si-Mn-Mg alloy. Mater. Trans. 2017, 58, 1624-1627. [CrossRef]

4. Ahn, C.; Jo, I.; Ji, C.; Cho, S.; Mishra, B.; Lee, E. Creep behavior of high-pressure die-cast $\mathrm{AlSi}_{10} \mathrm{MnMg}$ aluminum alloy. Mater. Charact. 2020, 167, 110495. [CrossRef]

5. Khoonsari, E.; Jalilian, F.; Paray, F.; Emadi, D.; Drew, R.A.L. Interaction of 308 stainless steel insert with A319 aluminium casting alloy. Mater. Sci. Technol. 2010, 26, 833-841. [CrossRef]

6. Jiang, W.; Fan, Z.; Li, G.; Li, C. Effects of zinc coating on interfacial microstructures and mechanical properties of aluminum/steel bimetallic composites. J. Alloy Compd. 2016, 678, 249-257. [CrossRef]

7. Jiang, W.; Fan, Z.; Li, G.; Liu, X.; Liu, F. Effects of hot-dip galvanizing and aluminizing on interfacial microstructures and mechanical properties of aluminum/iron bimetallic composites. J. Alloy Compd. 2016, 688, 742-751. [CrossRef]

8. Wróbel, T.; Wiedermann, J.; Skupień, P. Bimetallic castings in a chromium-nickel stainless steel working surface layer configuration with a grey cast iron base. Trans. Indian Inst. Met. 2015, 68, 571-580. [CrossRef]

9. Mola, R.; Bucki, T. Characterization of the bonding zone in AZ91/AlSi12 bimetals fabricated by liquid-solid compound casting using unmodified and thermally modified AlSi12 alloy. Stroj. Vestn. J. Mech. Eng. 2020, 66, 439-448. [CrossRef]

10. Ramadan, M.; Alghamdi, A.S.; Hafez, K.M.; Subhani, T.; Abdel Halim, K.S. Development and optimization of tin/flux mixture for direct tinning and interfacial bonding in aluminum/steel bimetallic compound casting. Materials 2020, 13, 5642. [CrossRef] [PubMed]

11. Liu, Y.; Bian, X.; Yang, J.; Zhang, K.; Feng, L.; Yang, C. An investigation of metallurgical bonding in Al-7Si/gray iron bimetal composites. J. Mater. Res. 2013, 28, 3190. [CrossRef] 
12. Springer, H.; Kostka, A.; Payton, E.J.; Raabe, D.; Kaysser-Pyzalla, A.; Eggeler, G. On the formation and growth of intermetallic phases during interdiffusion between low-carbon steel and aluminum alloys. Acta Mater. 2011, 59, 1586-1600. [CrossRef]

13. Bakke, A.O.; Arnberg, L.; Løland, J.-O.; Jørgensen, S.; Kvinge, J.; Li, Y. Formation and evolution of the interfacial structure in al/steel compound castings during solidification and heat treatment. J. Alloy Compd. 2020, 849, 156685. [CrossRef]

14. Jiang, W.; Fan, Z.; Li, C. Improved steel/aluminum bonding in bimetallic castings by a compound casting process. J. Mater. Process. Technol. 2015, 226, 25-31. [CrossRef]

15. Szymczak, T. The structure of connection of the AlSi5-HS6-5-2 compound casting obtained by alphinising. Arch. Foundry Eng. 2011, 11, 175-184.

16. Kundu, S.; Chatterjee, S. Characterization of diffusion bonded joint between titanium and 304 stainless steel using a Ni interlayer. Mater. Charact. 2008, 59, 631-637. [CrossRef]

17. Zhang, J.; Luo, G.-Q.; Shen, Q.; Zhang, L.-M.; Huang, Z.-J. Characterization of diffusion-bonded joint between $\mathrm{Al}$ and Mg using a Ni interlayer. Rare Met. 2016, 35, 537-542. [CrossRef]

18. Meng, F.; Wu, Y.; Hu, K.; Li, Y.; Sun, Q.; Liu, X. Evolution and strengthening effects of the heat-resistant phases in Al-Si Piston alloys with different Fe/Ni ratios. Materials 2019, 12, 2506. [CrossRef]

19. Awe, S.A.; Seifeddine, S.; Jarfors, A.E.W.; Lee, Y.C.; Dahle, A.K. Development of new Al-Cu-Si alloys for high temperature performance. Adv. Mater. Lett. 2017, 8, 695-701. [CrossRef]

20. Medrano-Prieto, H.; Garaz-Reyes, C.G.; Gomez-Esparza, C.D.; Estrada-Guel, I.; Aguilar-Santillan, J.; Maldonado-Orozco, M.C.; Martinez-Sanchez, R. Effect of Nickel addition and solution treatment time on microstructure and hardness of Al-Si-Cu aged alloys. Mater. Charact. 2016, 120, 168-174. [CrossRef]

21. Te, A.; Harrison, R.A.; Olson, S.D. Dissimilar Metal Casting; Worcester Polytechnic Institute: Worcester, MA, USA, 2016.

22. Pakzaman, H.; Divandari, M.; Khavandi, A. Effect of nickel coating on steel wire reinforcement on mechanical properties of aluminum matrix composites produced via lost foam casting. In Proceedings of the Iran International Aluminum Conference (IIAC2012), Arak, Iran, 15-16 May 2012.

23. Zolotorevsky, V.S.; Belov, N.A.; Glazoff, M.V. Casting Aluminum Alloys; Elsevier: Amsterdam, The Netherlands, 2007 ; Volume 12.

24. Seeger, A. The mechanisms of diffusion in metals and alloys. J. Less Common Met. 1972, 28, 387-418. [CrossRef]

25. Kobayashi, S.; Yakou, T. Control of intermetallic compound layers at interface between steel and aluminum by diffusion-treatment. Mater. Sci. Eng. A 2002, 338, 44-53. [CrossRef]

26. Jiang, W.; Li, G.; Wu, Y.; Liu, X.; Fan, Z. Effect of heat treatment on bonding strength of aluminum/steel bimetal produced by a compound casting. J. Mater. Process. Technol. 2018, 258, 239-250. [CrossRef]

27. Farkoosh, A.; Javidani, M.; Hoseini, M.; Larouche, D.; Pekguleryuz, M. Phase formation in as-solidified and heat-treated Al-Si-CuMg-Ni alloys: Thermodynamic assessment and experimental investigation for alloy design. J. Alloy Compd. 2013, 551, 596-606. [CrossRef]

28. Adabi, M.; Amadeh, A.A. Formation mechanisms of Ni-Al intermetallics during heat treatment of Ni coating on $6061 \mathrm{Al}$ substrate. Trans. Nonferrous Met. Soc. China 2015, 25, 3959-3966. [CrossRef]

29. Mondolfo, L.F. Aluminum Alloys: Structure and Properties; Elsevier: Amsterdam, The Netherlands, 2013.

30. Evans, H.; Lobb, R. Conditions for the initiation of oxide-scale cracking and spallation. Corros. Sci. 1984, 24, 209-222. [CrossRef]

31. Paul, A.; Laurila, T.; Vuorinen, V.; Divinski, S.V. Interdiffusion and the Kirkendall effect in binary systems. In Thermodynamics, Diffusion and the Kirkendall Effect in Solids; Springer: Cham, Switzerland, 2014; pp. 239-298.

32. Tavoosi, M. The Kirkendall void formation in $\mathrm{Al} / \mathrm{Ti}$ interface during solid-state reactive diffusion between $\mathrm{Al}$ and Ti. Surf. Interfaces 2017, 9, 196-200. [CrossRef]

33. Ma, Z.; Samuel, A.M.; Samuel, F.H.; Doty, H.W.; Valtierra, S. A study of tensile properties in Al-Si-Cu and Al-Si-Mg alloys: Effect of $\beta$-iron intermetallics and porosity. Mater. Sci. Eng. A 2008, 490, 36-51. [CrossRef]

34. Puncreobutr, C.; Lee, P.D.; Kareh, K.M.; Connolley, T.; Fife, J.L.; Phillion, A.B. Influence of Fe-rich intermetallics on solidification defects in Al-Si-Cu alloys. Acta Mater. 2014, 68, 42-51. [CrossRef]

35. Mbuya, T.; Odera, B.; Ng'ang'a, S. Influence of iron on castability and properties of aluminium silicon alloys: Literature review. Int. J. Cast Met. Res. 2003, 16, 451-465. [CrossRef]

36. Li, Y.; Yang, Y.; Wu, Y.; Wang, L.; Liu, X. Quantitative comparison of three Ni-containing phases to the elevated-temperature properties of Al-Si piston alloys. Mater. Sci. Eng. A 2010, 527, 7132-7137. [CrossRef]

37. Furukawa, M.; Horita, Z.; Nemoto, M.; Valiev, R.Z.; Langdon, T.G. Microhardness measurements and the Hall-Petch relationship in an Al-3\% Mg alloy with submicrometer grain size. Acta Mater. 1996, 44, 4619-4629. [CrossRef]

38. Krupiński, M.; Król, M.; Maniara, R. Heat treatment of Al-Si-Cu alloys. In Solid State Phenomena; Trans Tech Publications: Zurich, Switzerland, 2018. 